\title{
Congenital Cystic Adenomatoid Malformation of the Lung: A Case Report
}

\section{Sood $\mathrm{M}^{1}$}

\author{
${ }^{1}$ Dr. Mangla Sood, MBBS, MD, Registrar, Department of Paediatrics, IGMC, Shimla
}

Address for correspondence: Dr. Mangla Sood, E-mail: nishoosood@yahoo.com

\section{Introduction}

$(2$ ongenital cystic adenomatoid malformations (CCAM) of the lung are rare congenital cystic lung lesions that arise from excessive disorganized proliferation of tubular bronchial structures. The prenatal rate of detection of lung cysts at the routine 18-20-week scan is almost $100 \%$. However as gestation progresses the tracheobronchial tree becomes patent and the fluid within the cysts exits into the amniotic fluid and the cysts collapse, allowing the other lobes of the lung to develop normally. Only at birth do the cysts then expand and present in the newborn period with respiratory distress. In late childhood or in adult life, it can present as recurrent chest infections or even undergo malignant transformation. We report a case of Type II CCAM in newborn with brief review of literature.

\section{Case Report}

Full term male baby with birth weight $3.0 \mathrm{~kg}$ was born to a 24 years primigravida by normal vaginal delivery at hospital. Antenatal period was supervised and uncomplicated. The only USG done at second trimester was reported as normal. Baby cried soon after birth but developed respiratory distress at 6 hours of life for which he was shifted to newborn nursery. First examination in newborn nursery revealed normal vitals except for RR $74 /$ min. Baby was maintaining saturation above $89 \%$ on room air. Systemic examination was normal except for respiratory system. Air entry was decreased on right side with few crepts. Chest X-ray was done which showed opacification of right lung. Though there was no history to suggest sepsis or meconium aspiration, sepsis screen was sent and baby was started on intravenous antibiotics. Sepsis screen was negative, blood culture sterile and antibiotics were stopped after 7 days. Baby continued to have tachypnoea. ECHO was normal and ruled out congenital cardiac disease. Repeat chest x-ray (Fig: 1) on day 9 showed mass containing air-filled cysts with mediastinal shift and herniation of right lung to opposite side. CT-chest (Fig: 2) done on day 14 of life revealed multilocular cystic lesions with thin walls surrounded by normal lung parenchyma in right lung with herniation of lung towards left side. Baby underwent successful surgery on day 16 of life, remained on ventilator for 4 days post-op. He remained well for 15 days, but developed pneumothorax on right side after respiratory infection. It was treated successfully and baby was discharged. There was no other congenital malformation. He is under our follow-up since last seven months and is healthy and well thriving without any lung dysfunction.

Histopathological examination of the excised mass showed many normal-sized to dilated alveoli lined by flattened or low-cuboidal epithileum and containing blood and alveolar macrophages in the lumen. There were numerous relatively uniform cysts measuring 0.5-2 $\mathrm{cm}$ in diameter resembling bronchioles, lined by stratified columnar epithileum and having a thin fibromuscular wall that showed the focal presence of skeletal muscles (Fig. 3). 
Table 1: Pathologic Features of Congenital Cystic Adenomatoid Malformation (according to Stocker) ${ }^{5}$

\begin{tabular}{|l|c|c|c|c|c|}
\hline Classification & Type 0 & Type 1 & Type 2 & Type 3 & Type 4 \\
\hline Frequency (\%) & $1-3$ & $>65$ & $20-25$ & 8 & 10 \\
\hline $\begin{array}{l}\text { Cyst size } \\
\text { (maximum) }\end{array}$ & $0.5 \mathrm{~cm}$ & $0.5-10 \mathrm{~cm}$ & $0.5-2 \mathrm{~cm}$ & $0.3-0.5 \mathrm{~cm}$ & $7 \mathrm{~cm}$ \\
\hline Epithelial lining & $\begin{array}{c}\text { Ciliated, } \\
\text { pseudostratified } \\
\text { columnar }\end{array}$ & $\begin{array}{c}\text { Cuboidal cells, } \\
\text { flattened, } \\
\text { columnar }\end{array}$ & $\begin{array}{c}\text { Ciliated } \\
\text { cuboidal, ciliated } \\
\text { pseudostratified }\end{array}$ & $\begin{array}{c}\text { Ciliated } \\
\text { cuboidal, } \\
\text { columnar }\end{array}$ & $\begin{array}{c}\text { Type } 1 \& 2 \\
\text { alveolar lining } \\
\text { cells }\end{array}$ \\
\hline $\begin{array}{l}\text { Muscular wall } \\
\text { thickness (mm) }\end{array}$ & $100-500$ & $100-300$ & $50-100$ & $0-50$ & $25-100$ \\
\hline Mucus cells & Present in all cases & $\begin{array}{c}\text { Present (33\% of } \\
\text { cases) }\end{array}$ & Absent & Absent & Absent \\
\hline Cartilage & Present in all cases & $\begin{array}{c}\text { Present (5-10\% } \\
\text { of cases) }\end{array}$ & Absent & Absent & Rare \\
\hline Skeletal muscle & Absent & Absent & $\begin{array}{c}\text { Present (5\% of } \\
\text { cases) }\end{array}$ & Absent & Absent \\
\hline
\end{tabular}

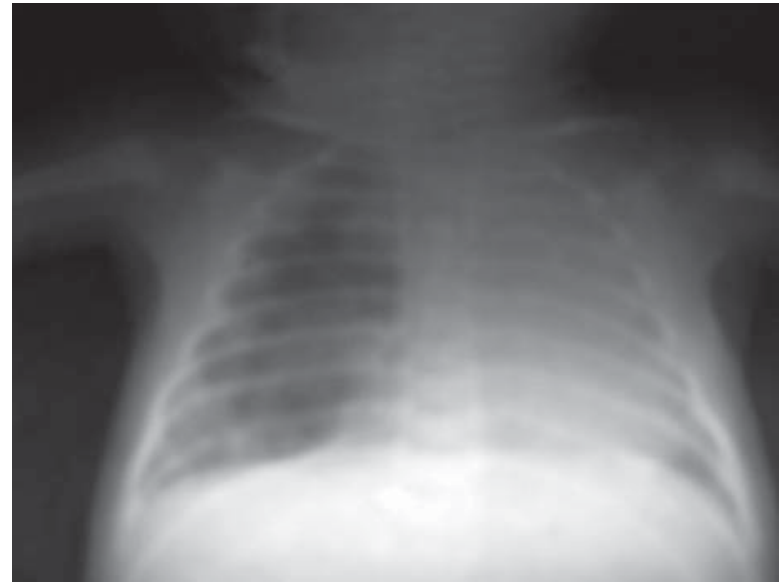

Fig 1: Chest X-ray of the baby showing opacification of right lung.

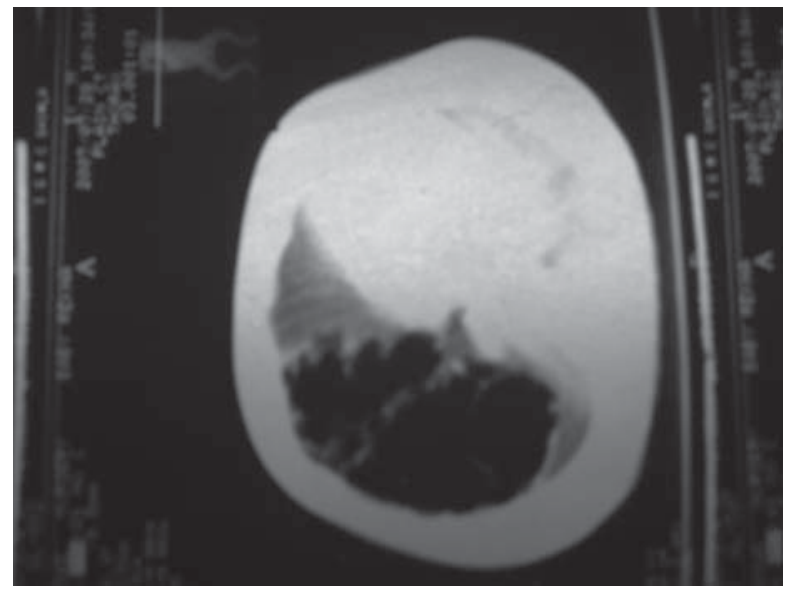

Fig 2: CT chest of the baby showing multilocular cystic lesions with thin walls surrounded by normal lung parenchyma in right lung with herniation of lung towards left side.

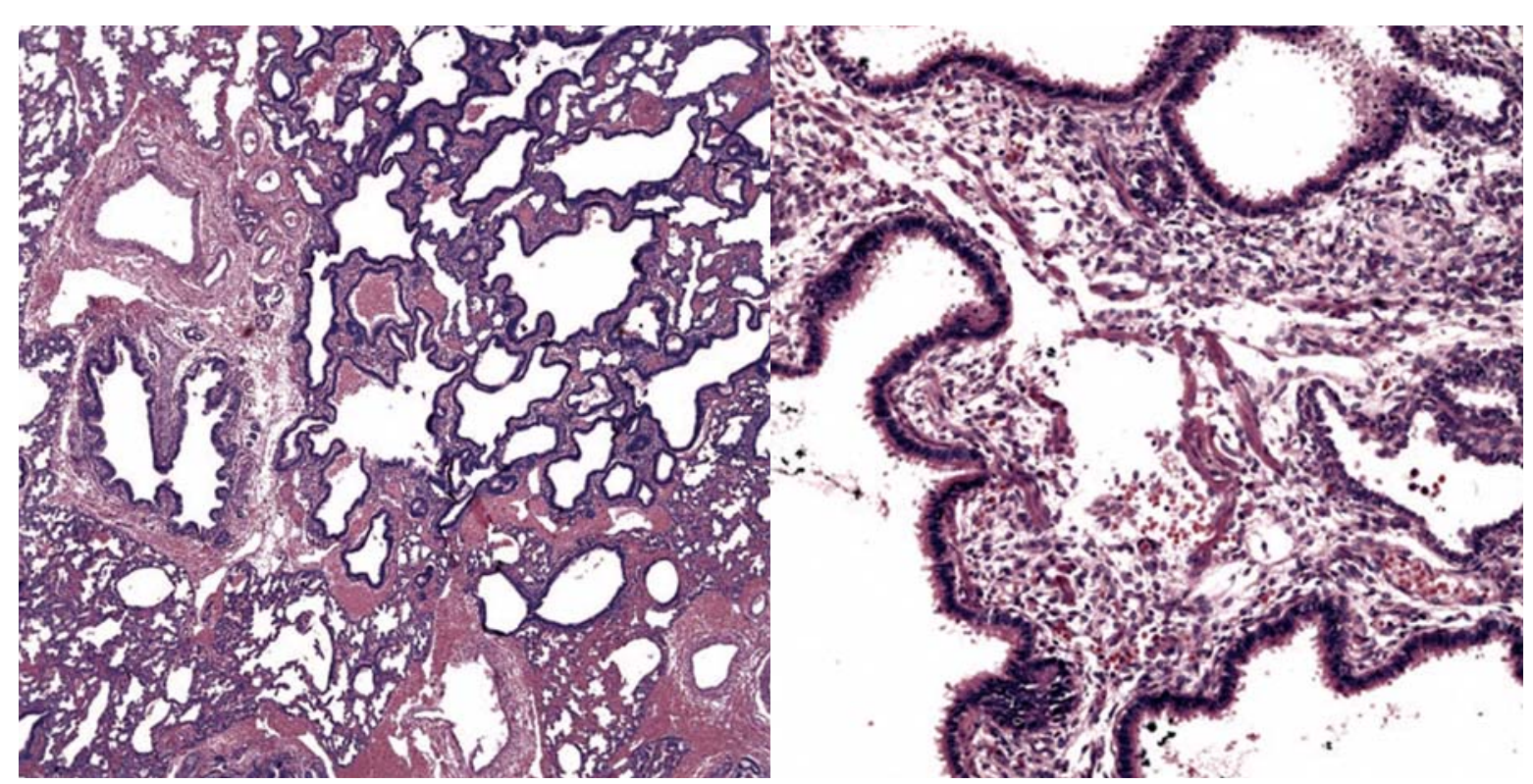

Fig 3: Histopathology of the lesion showing multiple bronchioles like structures with intervening connective tissue showing bands of well differentiated skeletal muscle which is characteristic of CCAM- 2 


\section{Discussion}

Congenital cystic adenomatoid malformations (CCAM) of the lung are rare development anomaly with incidence of $1: 25,000$ to $1: 35,000$ in literature with males and females equally affected ${ }^{1}$. The lesions are benign hamartomatous or dysplastic lung tumor characterized by overgrowth of terminal bronchioles with reduction in alveoli ${ }^{1} .80 \%$ cases present in newborn period with almost equal frequency in premature and term infants. It is usually unilateral and restricted to a single lobe ${ }^{2}$. In, up to $10 \%$ of the cases additional extra-pulmonary abnormalities can be found, such as renal, central nervous, gastrointestinal, and cardiac defects ${ }^{3}$.

The development of the vertebrate lung has been subdivided into five distinct periods based on the anatomical changes that occur in lung architecture: embryonic (3-7 weeks), pseudoglandular (7-17 weeks), canalicular (17-29 weeks), saccular (24-36 weeks), and alveolar (36 weeks to maturity). The CCAM develops during the pseudoglandular and saccular period (735 weeks) $)^{4}$.

Stocker, Madewell, and Drake using clinical and pathologic features based on site of origin of the malformation (e.g., tracheal, bronchial, bronchiolar, bronchiolar/alveolar duct and alveolar/distal acinar) divided CCAM into three subtypes in $1977^{4}$ and later added two more subtypes in 20025: (1) type 0 - acinar dysplasia, (2) type I - multiple large cysts or a single dominate cyst, (3) type II - multiple evenly spaced cysts, (4) type III - bulky firm mass, (5) type IV - peripheral cyst type. (Table-1) Stocker's classification does not accurately describe CCAMs detected antenatally. Adzick et al classifies antenatally detected cystic lung lesions into two types: macrocystic with size $>5 \mathrm{~mm}$ (type 1 ) and microcystic with size $<5 \mathrm{~mm}$ (type 2$)^{6}$.

The differential diagnosis includes lobar sequestration, bronchogenic cyst, congenital lobar emphysema, or congenital diaphragmatic hernia. Antenatally it can lead to fetal hydrops, and maternal polyhydramnios, with anticipated mortality $100 \%$ with fetal hydrops without lung decompression in utero using resection of lobe or thoracoamniotic shunts ${ }^{7}$. Fifteen to $50 \%$ of CCAMs decrease in size significantly before birth $^{7,8}$. Complete postnatal resolution is rare, and apparent spontaneous "disappearance" of antenatally diagnosed lesions should be followed carefully, as nearly half of these cases subsequently require surgery ${ }^{9}$. Ultrasound, CT and MRI are used to identify the location and appearance of the lung abnormality, and determine any changes in thoracic position of other lung lobes, mediastinum, renal (renal agenesis) and gastrointestinal (diaphragmatic hernia and bowel atresia) systems and the cardiac structures. The blood supply and venous drainage is evaluated by Doppler ultrasound. CCAM has both its arterial and venous blood flow from the pulmonary system, whereas in lung sequestration the aorta, rather than the pulmonary artery is the source of blood supply, and there is no communication with the bronchial tree ${ }^{10}$

Delivery should be conducted at specialised centre. Respiratory distress including cyanosis, retractions, and grunting is the most common presentation in the newborn period $^{9,11}$ due to cysts expanding and compressing their surrounding structures leading to pulmonary hypoplasia, mediastinal shift, spontaneous pneumothorax, or pleural effusion due to hydrops.. Symptomatic lesions require urgent radiological evaluation with chest radiography and ideally a CT scan, followed by surgical excision. Later in life morbidity from infection resulting in recurrent pneumonia, lung abscess, empyema, pneumothorax, or, more rarely, malignancy has been reported ${ }^{8}, 12,13,15$. For asymptomatic cases some centre advocate conservative management ${ }^{14,16}$. Surgery is postponed if the patient is asymptomatic but CT chest is done within 1 month postnatally in all cases to delineate the thoracic lesion, demonstrate any connection with the tracheobronchial tree, and most importantly evaluate the blood supply so that surgery can be performed in a planned manner due to long term risks. Long term outcome is very good for surgically managed asymptomatic patients, affected children leading normal lives with only slight decrease in lung volume?.

\section{References}

1. Laberge JM, Flageole H, Pugash D, et al. Outcome of the prenatally diagnosed congenital cystic adenomatoid lung malformation: a Canadian experience. Fetal Diagn Ther 2001; 6:178-186.

2. Davenport M, Warne SA, Cacciaguerra S, et al. Current outcome of antenally diagnosed cystic lung disease. J Pediatr Surg 2004; 39:549-556.

3. Stocker JT. Congenital and developmental diseases. In: Dail DH, Hammer SP, editors. Pulmonary pathology, New York: Springer. 1994; 2nd ed:174-180.

4. Stocker JT, Madewell JE, Drake RM. Congenital cystic adenomatoid malformation of the lung. Classification and morphologic spectrum. Hum Pathol 1977; 8: 155-171.

5. Stocker JT. Congenital pulmonary airway malformation: a new name for and an expanded 
classification of congenital cystic adenomatous malformation of the lung. Histopathology 2002; 41(Suppl 2):424-431.

6. Adzick NS, Harrison MR, Glick PL, et al. Fetal cystic adenomatoid malformation: prenatal diagnosis and natural history. J Pediatr Surg 1985; 20:483-488.

7. Gornall AS, Budd JL, Draper ES, et al. Congenital cystic adenomatoid malformation: accuracy of prenatal diagnosis, prevalence and outcome in a general population. Prenat Diagn 2003; 23:9971002.

8. Ozcan C, Celik A, Ural Z, et al. Primary pulmonary rhabdomyosarcoma arising within cystic adenomatoid malformation: a case report and review of the literature. J Pediatr Surg 2001; 36:1062-1065.

9. Calvert JK, Boyd PA, Chamberlain PC, et al. Outcome of antenatally suspected congenital cystic adenomatoid malformation of the lung: 10 years' experience 1991-2001. Arch Dis Child Fetal Neonatal Ed 2006; 91:F26-28.

10. Cass DL, Crombleholme TM, Howell LJ, et al. Cystic lung lesions with systemic arterial blood supply: a hybrid of congenital cystic adenomatoid malformation and bronchopulmonary sequestration. J Pediatr Surg 1997; 32:986-990.
11. Calvert JK, Lakhoo K. Antenatally suspected congenital cystic adenomatoid malformation of the lung: postnatal investigation and timing of surgery. J Pediatr Surg 2007; 42:411-414.

12. Giardikis S, Didilis V, Polychronidis A, et al. Spontaneous pneumothorax resulting from congenital cystic adenomatoid malformation in a preterm infant: case report and literature review. Eur J Pediatr Surg 2002; 12:195-198.

13. Boon D, Llewellyn T, Rushton P. A strange case of a tension pneumothorax. Emerg Med J 2002; 19:470-471.

14. Douglas R W., Hedrick H L, Liechty K W, Flake A W, Johnson M P, Bebbington M, Adzick N S. Cystic adenomatoid malformation of the lung: Review of genetics, prenatal diagnosis, and in utero treatment. Amer J Med Genetics 2006;140:151155.

15. Ribet ME, Copin MC, Soots JG, Gosselin BH. Bronchoalveolar carcinoma and congenital cystic adenomatoid malformation. Ann Thorac Surg 1995; 60:1126-1128.

16. Chetcuti PA, Crabbe DC. CAM lungs: the conservative approach. Arch Dis Child Fetal Neonatal Ed 2006; 91:F463-464.

\section{How to cite this article?}

Sood M. Congenital Cystic Adenomatoid Malformation of the Lung. A Case Report. J Nepal Paedtr Soc 2011;31(1):64-67. 